\title{
Pensononowoor
}

2018, vol. 80, 24-36

http://dx.doi.org/10.12657/denbio.080.003

\author{
Leszek Bujoczek, Małgorzata Bujoczek
}

\section{The dynamics of the Taxus baccata L. population and the factors affecting its regeneration in the Jasień Nature Reserve}

Received: 5 January 2018; Accepted: 23 July 2018

\begin{abstract}
Taxus baccata L. is a relict plant and has a scattered distribution in the entire species range. Yew regeneration may be affected by moisture conditions and tree stand characteristics - variables which change over time and which have not been sufficiently researched to date. The present study determined the size structure of yews, causes of yew mortality, the effects of tree stand characteristics and habitat conditions on yew diameter increment at breast height, the density of yew seedlings and saplings, and the likelihood of yew seedling occurrence.

The study was conducted in central Poland, on 22 permanent sampling plots. The paper presents data collected in 2017 with reference to previous studies on these plots from 2001 and 2007. Stand volume, basal area, number of trees, canopy cover, and type of forest site were established for the tree layer. Saplings and shrubs were counted. Finally, the parameters determined for yew seedlings included density and percentage of individuals damaged by browsing, as well as soil moisture and percentage cover of herbaceous vegetation in the nearest neighborhood.

In 2017, yew density in the tree layer was 70 individuals/ha, having increased by 15 individuals/ha over 16 years. During that period, 6.4 individuals/ha died in that layer. The predominant cause of yew mortality was wind. In the period 2007-2017, the mean diameter increment at breast height was $2.2 \mathrm{~mm} /$ year, and indicated a weak relationship only with tree diameter at the beginning of the studied period $\left(\mathrm{R}^{2}=0.06\right)$. In 2017, the mean density of yew saplings and seedlings was 55 individuals/ha and 1005 individuals/ha, respectively. Two independent variables were found to be significant in the model of yew seedling occurrence: presence of mature yews on the sampling plot and soil moisture.

The condition of the studied yew population is satisfactory, especially in the less moist areas. The number of seedlings is acceptable, but more active protection should be considered due to the scarcity of yew saplings. This is all the more important as seed-producing mature yews tend to die as a result of exposure to strong winds and periodic local flooding.
\end{abstract}

Keywords: English yew, seedlings, saplings, diameter increment, diameter distribution, mortality

Address: L. Bujoczek, University of Agriculture in Krakow, Faculty of Forestry, Department of Forest Management, Geomatics and Forest Economics, Al. 29 Listopada 46, 31-425 Krakow, Poland, e-mail: leszek.bujoczek@ur.krakow.pl

M. Bujoczek, University of Agriculture in Krakow, Faculty of Forestry, Department of Forest Biodiversity, Al. 29 Listopada 46, 31-425 Krakow, Poland 


\section{Introduction}

The English yew (Taxus baccata L.) is a slow-growing but long-lived species (Pridnya, 2002). Its optimum growth conditions include fertile humus-rich loamy sand and loam soils with good hydrological and aeration properties. It does not grow well on dry, nutrient-poor sandy soils or on excessively wet or peaty soils (Bugała, 1975).

Within its natural range, it is thought to be threatened, being locally extinct or declining (Thomas \& Polwart, 2003; Kassioumis et al., 2004; Dhar et al., 2006; Ruprecht et al., 2010; Iszkuło et al., 2016). The underlying causes of yew decline include human pressure, excessive shading, browsing, poor competitive ability, changes in water table depth, droughts, fungal infections, and competition from other species (Iszkuło, 2001; Thomas \& Polwart, 2003; Frydel \& Nawrocka-Grzeskowiak, 2009; Iszkuło et al., 2012a; Iszkuło et al., 2014; Devaney et al., 2015; Garbarino et al., 2015). Many studies on this tree species emphasize its poor regeneration and a scarcity of saplings in natural stands (Gieruszyński, 1961; Iszkuło \& Boratyński, 2006; Ruprecht et al., 2010). There are far fewer data on the development of local populations or the scale of regeneration (Seidling, 1999; Giertych, 2000; Dhar et al., 2006).

Under natural conditions, the yew rarely forms pure forest stands and is typically scattered among other species. In the vertical structure of tree stands, it typically occurs in the lower layers, under the canopy of other species (Król \& Gołąb, 1996). Light conditions have a significant effect on the survival, growth and development of plants, with adaptation processes leading to modifications in leaf morphology (Wyka et al., 2008; Devaney et al., 2015). Yew is a very shade tolerant species (Thomas \& Polwart, 2003), but there is considerable variation in its mortality under similarly low light conditions (e.g., Iszkuło, 2010; Perrin \& Mitchell, 2013). The absence of yew seedlings is often attributed to the dense shade cast by the canopies of mature trees (Svenning \& Magård, 1999). On the other hand, yew seedlings are susceptible to photoinhibition if exposed to full light (Robakowski \& Wyka, 2009). In turn, saplings and mature yews can tolerate high light availability (Thomas \& Polwart, 2003; Myking et al., 2009). In summary, the response of yews to light depends on their age and/or developmental stage (Devaney et al., 2015).

It is likely that climate change will pose an increasing threat to yews (Thomas \& Garcia-Marti, 2015). The range of the species covers Europe, Algeria, and Anatolia; within Europe it extends from the Azores to southern Norway and Sweden in the north, and as far as northern Iran in the east (Hultén \& Fries, 1986). Across the majority of the yew range overall temperature and precipitation changes over the next century will probably have little effect by themselves on the growth of new trees. In turn, at the southern end of the yew range and in the drier areas of the north of its range, the likely causes of yew retreat are increased evapotranspiration and reduced water availability. While on wetter northern sites climatic conditions are more favorable, yew spread is nevertheless restricted due to poorer reproduction attributable to population fragmentation, reduced pollen production, and limited seed movement (Thomas \& Garcia-Marti, 2015). Researchers have also addressed the effects of climate change on the occurrence of strong winds damaging tree stands (Seidl et al., 2014; Trapp \& Hoogewind, 2016). Windthrows may significantly affect local yew populations by reducing their size (Baluta \& Mowszowicz, 1966). Nevertheless, despite the fact that the yew generally forms small populations, the species is highly vigorous and the mortality of adult individuals in the studied areas is rather low (Adamczyk, 2011; Katsavou \& Ganatsas, 2012).

In Poland, the yew is scattered among numerous stands, most of which are located in the Pomeranian Lakeland, Silesia, Lesser Poland, and Subcarpathia, as well as in the Holy Cross (Świętokrzyskie) Mountains. Yews grow in coniferous or mixed stands usually consisting of beech, fir, oak, hornbeam, lime, and spruce (Król \& Gołąb, 1996). Currently, moist coniferous forests and alder swamp forests with an abundance of yews are very rare. However, paleobotanical studies on the Mazovian Interglacial indicate that during that period the yew may have been the dominant species in such habitats (Krupiński et al., 2004).

Substantial research efforts are now under way to elucidate the diversity and genetic variability of yews in different regions (Zarek, 2009; Nawrocka-Grześkowiak et al., 2015; Zarek, 2016; Litkowiec et al., 2018). This is significant with a view to appropriate selection of propagation material for further production and is associated with the implementation of a yew protection and restoration program introduced by the Decision of the General Director of State Forests (2006). Currently, the species is subject to partial conservation by the Directive of the Minister of the Environment (2014), while a decade ago it was still strictly protected, being entered in the Polish Red Book of Plants as vulnerable (Kruszelnicki, 2001).

The pressure of various factors on a yew population depends on the specific features of a given area, being considerably modified by different habitats, protection statuses, and stand characteristics. Repeated measurements of the same yew trees over a long period of time afford an understanding of population dynamics, as well as the growth of individuals, their survivorship, and causes of mortality. In addition, the determination of the habitat and stand 
characteristics influencing regeneration and the occurrence of yew seedlings enables optimization of protection measures. The main objectives of the presented study were to investigate the following processes in a yew population at a local level over a 16-year period of observation: (i) changes in yew diameter structure; (ii) the dynamics of diameter increments; (iii) the causes of mature yew mortality; (iv) yew regeneration density, and (v) the factors affecting the likelihood of regeneration.

\section{Materials and methods}

\section{Study area}

The study involved the Jasien Nature Reserve located in central Poland $\left(50^{\circ} 59^{\prime} 55.1^{\prime \prime} \mathrm{N}, 1^{\circ} 33^{\prime} 56.8^{\prime \prime} \mathrm{E}\right.$, Fig. 1). The reserve, with a forest area of 19.33 ha, was established in 1958 to conserve a natural stand of the English yew. Its soils mainly fall into two categories: degraded podzols on wet, strongly gleyed loose sands, and boggy soils. The two identified types of forest sites are moist coniferous forest (5.44 ha) and alder swamp forest (13.89 ha). The former is dominated by Pinus sylvestris L. and Betula pendula Roth, and the latter by Alnus glutinosa (L.) Gaertn (Plan of Forest Management, 1984; Bujoczek et al., 2009). Plant associations are not specified for the moist coniferous forest area, while in the remaining part of the nature reserve the vegetation represents two partially overlapping communities: Circaeo-Alnetum OBERD. 1953 and Carici elongatae-Alnetum KOCH 1926 (Mowszowicz \& Urbanek, 1960; Urbanek, 1960). However, it should be noted that the plant associations in the studied area are not very distinct, which caused some problems with phytosociological identification. The reserve partially borders on fish ponds and due to capillary rise the water table remains very high (0.3-0.6 m below surface). In addition, parts of the reserve are occasionally flooded by the streams that run through them.

The yew population in this area was studied several times during the 20th century. Data from the beginning of that century indicate numerous yews on the site, but approximately 100 years ago many trees with a diameter at stump of $14-37 \mathrm{~cm}$ were felled, with 4000-6000 mostly young individuals remaining within the boundary of today's reserve (Malitowski, 1922). The tree stand continued to be devastated by the local inhabitants and grazing cattle, and numerous yews were damaged by the harsh winter of $1928 / 29$. As a result, subsequent works reported a decline in the number of yews, with only 361 identified in 1930 (Kotkowski, 1930). The situation did not improve until the area was brought under official protection and fenced in result of Decision of Minister of Forestry and Wood Industry (1958), which prevented further cattle grazing in this area. In 1959, there were 1912 individuals higher than $50 \mathrm{~cm}$, but only 3 had a diameter at breast height (DBH) greater than $7 \mathrm{~cm}$, with the largest one being $11 \mathrm{~cm}$ wide

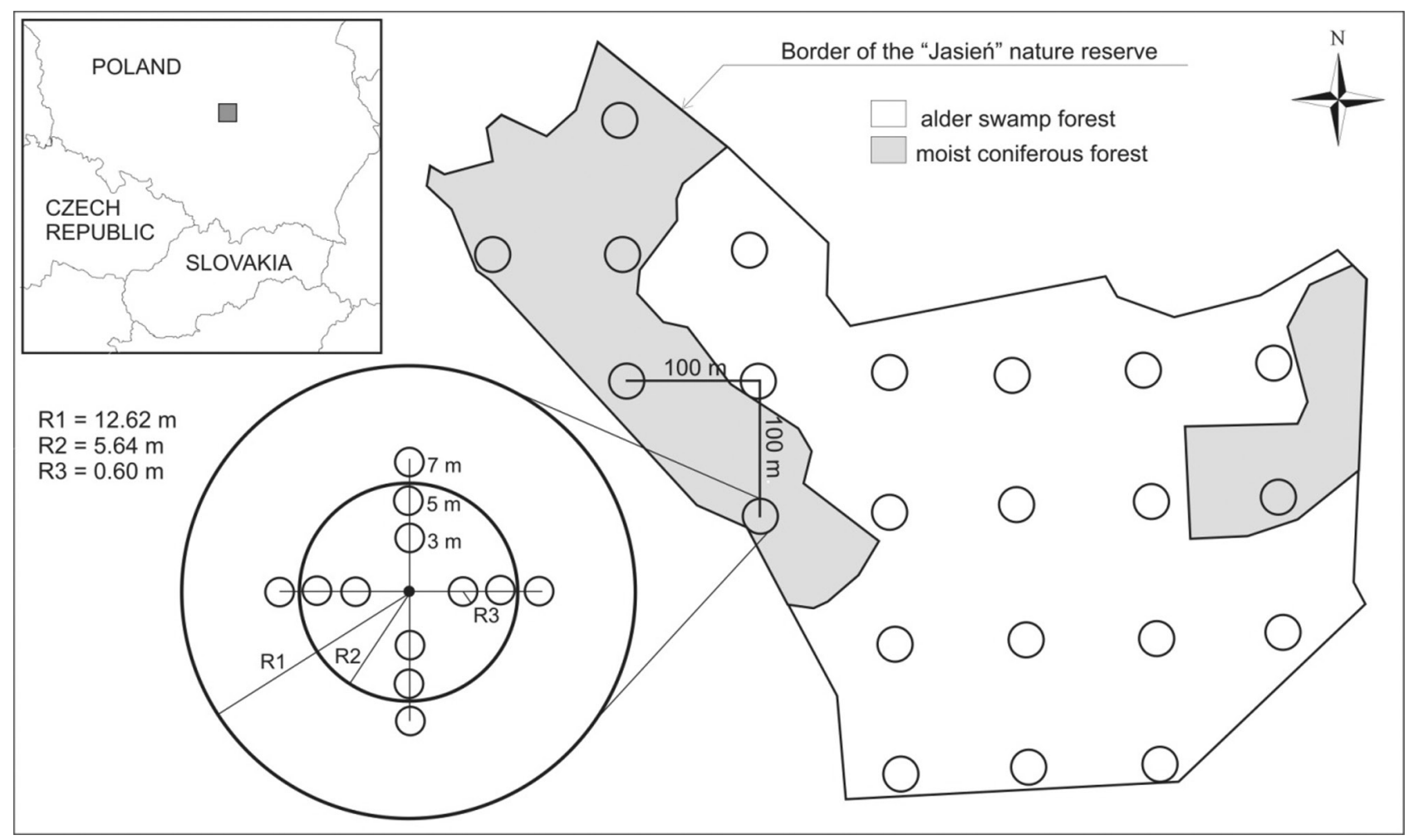

Fig. 1. The study area and location, and size of sampling plots 
(Mowszowicz \& Urbanek, 1960). Finally, it should be noted that there is no literature information on when the fence was eventually torn down (with no extant remains). The reserve, according to its status, is currently under active protection (Decision of the Regional Director of the Environment Protection 2013), but since the beginning of our research, we have not observed any treatments in this area.

\section{Field study}

Measurements were conducted in 2017 in the Jasień Nature Reserve as a continuation of studies from 2001 and 2007 (Bujoczek et al., 2009). The tree layer was defined as all individuals with $\mathrm{DBH} \geq 7 \mathrm{~cm}$ (which are hereafter referenced as "mature trees", especially as concerns yews). The polar coordinates and DBH of all trees were measured on 22 permanent sampling plots with an area of 0.05 ha each (R1 in Fig. 1). DBH was measured with an accuracy of $1 \mathrm{~mm}$, with the arm of the caliper always facing the center of the sampling plot to ensure comparability between studies. The light conditions of the yew canopy cover were estimated visually as a percentage from $0 \%$ to $100 \%$ for each sampling plot, with a resolution of $5 \%$. Canopy cover was understood as the part of the sampling plot covered by the vertical projection of tree crowns on a horizontal plane. Using reference data from the 2001 and 2007 measurements, trees which reached a DBH of $7 \mathrm{~cm}$ during the 2001-2007 and 2007-2017 observation periods, respectively, as well as those which died for whatever reason during that time, were recorded. Probable causes of yew mortality were determined based on their appearance and situation on the surface. In the case of downed trees, their position with respect to one another was considered. Flooding was deemed the cause of yew mortality if the dead trees were found in an inundated area and no damage to the stem or crown was identified. Such determinations were made on the basis of records from several field visits and observations of small groups of dead yews in flooded areas also outside sampling plots.

In each of the 22 sampling plots, 0.01 ha concentric circles (R2 in Fig. 1) were designated, within which saplings and shrubs (of all species including yew with a height of $>0.5 \mathrm{~m}$ and DBH $<7 \mathrm{~cm}$ ) were counted. Saplings and shrubs were classified into three size groups: less than $1.3 \mathrm{~m}$ high, with DBH 0.1-3.9 cm, and with DBH 4-6.9 cm. Also, the height of trees with $\mathrm{DBH} \geq 7$ was measured within a circle with a diameter R2 using a Vertex IV device, with the measurements rounded off to the nearest $1 \mathrm{~m}$. In 2017, 264 additional subplots with a diameter of 1.2 m (R3 in Fig. 1) were established to study yew seedlings (12 subplots per sampling plot). Yew seedlings (with a height $\leq 0.50 \mathrm{~cm}$ ) were classified into the following size classes by height: less than $10 \mathrm{~cm} ; 11-20 \mathrm{~cm} ; 21-30 \mathrm{~cm} ; 31-40 \mathrm{~cm}$; and $41-50$ $\mathrm{cm}$. Furthermore, it was recorded whether or not a given yew seedling was damaged by browsing. The seedling count was accompanied by a study of herbaceous vegetation to evaluate percentage ground cover by the various species. Based on ecological indicator values for the vascular plants of Poland, each species was assigned a soil moisture value on a 6-point scale (Zarzycki et al., 2002): dry, fresh, moist, wet, aquatic (no species was found for very dry conditions).

\section{Data analysis}

Each sampling plot was ascribed a forest site type based on a habitat map (Plan of Forest Management, 1984). Tree volume for trees growing within a circle with the diameter R2 was calculated using volume tariffs developed on the basis of trees for which DBH and height were measured. The volume of those trees was read from tables (Czuraj, 1990). Based on those trees, curves representing the relationship between DBH and volume were plotted for the various tree species. This relationship was used to determine the volume of the remaining trees, for which only $\mathrm{DBH}$ was known. The calculation procedure and the formulas used are given in the work of Warcicki (2001).

Changes in the DBH structure of yew trees were analyzed using data from three consecutive measurements conducted in 2001, 2007, and 2017. The yews in the tree layer which died in the observation periods 2001-2007 and 2007-2017 were characterized by their DBH from the beginning of a given period.

The DBH increment for individual yews was determined as the difference between the 2017 and 2007 measurements, and expressed in $\mathrm{mm}$. The effects of stand and habitat characteristics on the diameter increment were evaluated using a multiple regression model with the variables listed in Table 1.

Spearman rank correlations were used to assess relationships between all independent variables for a given sampling plot (stand volume, basal area, tree density, canopy cover, sapling and shrub density, number of English yews in the tree layer, soil moisture, and herbaceous vegetation density).

Yew seedling density was analyzed for the various height classes. The significance of differences was evaluated using the Kruskal-Wallis test. The factors affecting the likelihood of seedling occurrence on a given plot were analyzed using logistic regression analysis (Larose, 2008). Each of the 22 sampling plots was considered to be a separate component for which the presence or absence of yew seedlings was indicated as 1 and 0 , respectively. The subplots were located close to one another, and a similar composition of the herbaceous vegetation indicated similar site conditions. Thus, data from 12 subplots were 
Table 1. Stand characteristics for 22 sampling plots

\begin{tabular}{|c|c|c|c|}
\hline Variable & Mean (Standard deviation) & Min-Max & Model $^{2}$ \\
\hline Stand volume in $2007\left[\mathrm{~m}^{3} \mathrm{ha}^{-1}\right]$ & $420(84)$ & $283-590$ & R; DI \\
\hline Stand volume in $2017\left[\mathrm{~m}^{3} \mathrm{ha}^{-1}\right]$ & $478(93)$ & $337-682$ & $\mathrm{R} ; \mathrm{DI}$ \\
\hline Basal area of stand in $2007\left[\mathrm{~m}^{2} \mathrm{ha}^{-1}\right]$ & $38.3(6.7)$ & $26.7-51.4$ & $\mathrm{R} ; \mathrm{DI}$ \\
\hline Basal area of stands in $2017\left[\mathrm{~m}^{2} \mathrm{ha}^{-1}\right]$ & $41.4(7.1)$ & $28.5-58.5$ & $\mathrm{R} ; \mathrm{DI}$ \\
\hline Stand density in 2007 [trees ha $\left.{ }^{-1}\right]$ & $756(271)$ & $380-1360$ & $\mathrm{R} ; \mathrm{DI}$ \\
\hline Stand density in 2017 [trees ha ${ }^{-1}$ ] & $722(245)$ & $320-1120$ & $\mathrm{R} ; \mathrm{DI}$ \\
\hline Sapling and shrub density in 2017 [individuals ha ${ }^{-1}$ ] & $16150(8756)$ & $6000-45300$ & $\mathrm{R}$ \\
\hline Canopy cover in 2017 [\%] & $49(15)$ & $20-75$ & $\mathrm{R} ; \mathrm{DI}$ \\
\hline Diameter of English yew in 2007 [cm] & $10.7(3.1)$ & $7.0-23.3$ & DI \\
\hline Habitat conditions & \multicolumn{2}{|c|}{ Type of site: moist coniferous forest and alder swamp forest } & $\mathrm{R} ; \mathrm{DI}$ \\
\hline Soil moisture based on herbaceous vegetation ${ }^{1}$ & $70.1(32.4)$ & $0-100$ & $\mathrm{R}$ \\
\hline Herbaceous vegetation density [\%] & $73.2(20.4)$ & $40-100$ & $\mathrm{R}$ \\
\hline Number of mature yews per sampling plot [trees $\left./ 0.05 \mathrm{ha}^{-1}\right]$ & $3.5(4.4)$ & $0-16$ & $\mathrm{R}$ \\
\hline Presence of mature yews in the tree layer & \multicolumn{2}{|c|}{ Dichotomous variable: 0 - absence; 1 - presence. } & $\mathrm{R}$ \\
\hline
\end{tabular}

${ }^{1}$ The variable "soil moisture" expresses the ground cover proportion of herbaceous plants characteristic of moist, wet, and aquatic sites (Zarzycki et al., 2002) as compared to plants typical of the less moist sites.

${ }^{2}$ Variables used in developing models for: $\mathrm{R}$ - regeneration; DI - diameter increment at breast height.

combined at the plot level. In this way, one mean value was obtained for herbaceous vegetation representing its density, as well as soil moisture, for each of the 22 sampling plots. Based on ecological indicator values for the vascular plants of Poland, each species was assigned a soil moisture value on a 6 -point scale (Zarzycki et al., 2002), with 2 - dry, 3 - fresh, 4 moist, 5 - wet, 6 - aquatic (no species had a moisture value of 1 - very dry and also very few species were assigned to the extreme moisture conditions, that is, 2 - dry and 6 - aquatic). Some species with greater tolerance for moist conditions were described as 3-4 - fresh-moist or 4-5 - moist-wet. The soil moisture variable used in statistical analysis expresses the ground cover proportion of species characteristic of moist, wet, and aquatic sites as compared to plants typical of the less moist sites, that is, dry, fresh, and fresh-moist. The resulting soil moisture variable ranged from $0 \%$ (no plants characteristic of moist, wet, or aquatic sites on the sampling plot) to $100 \%$ (all plants on the sampling plot were characteristic of such sites). The sampling plots were also described in terms of variables characterizing the tree stand, saplings and shrubs (Table 1). A model was built using the step-wise forward method and the odds ratio was calculated. An increase or decrease in independent variables by one unit increased or decreased the likelihood of yew seedling occurrence by the odds ratio. The independent variables were tested for the presence of intercorrelations. Cox-Snell coefficients, Nagelkerke values, and the Hosmer-Lemeshow test were used as quality characteristics of the model (Introduction to SAS, 2007; Larose, 2008). A successful classification test was carried out on the basis of those observations that were used to estimate the parameters of the model (Menard, 2001). Calculations were performed using STATISTICA 13 software.

\section{Results}

In 2017, the stand was characterized by a volume of $478 \mathrm{~m}^{3} /$ ha at a tree density of 722 individuals/ha (Table 1). The tree layer was found to consist of 16 species. The most abundant of them in the moist coniferous forest were: Pinus sylvestris (41\% share in stand volume), Betula pendula (33\%), Alnus glutinosa (9\%), Quercus sp. (7\%), and Picea abies (L.) H. Karst. (6\%). In the alder swamp forest, the main species were: Alnus glutinosa (82\%), Betula pendula (6\%), Acer pseudoplatanus L. (5\%), and Picea abies (3\%). The mean density of saplings and shrubs in the reserve was 16150 individuals/ha. The density of yews with $\mathrm{DBH} \geq 7 \mathrm{~cm}$ was $70.0 \pm 19.0$ ( \pm standard error) individuals/ha. No significant correlations were found between the independent variables describing the tree stand and the number of yews on the sampling plots (Table 2). Since 2001 , yew density has increased on average by 15.5 individuals/ha. Over that time, an average of 21.8 individuals/ha were recruited from the sapling layer to the

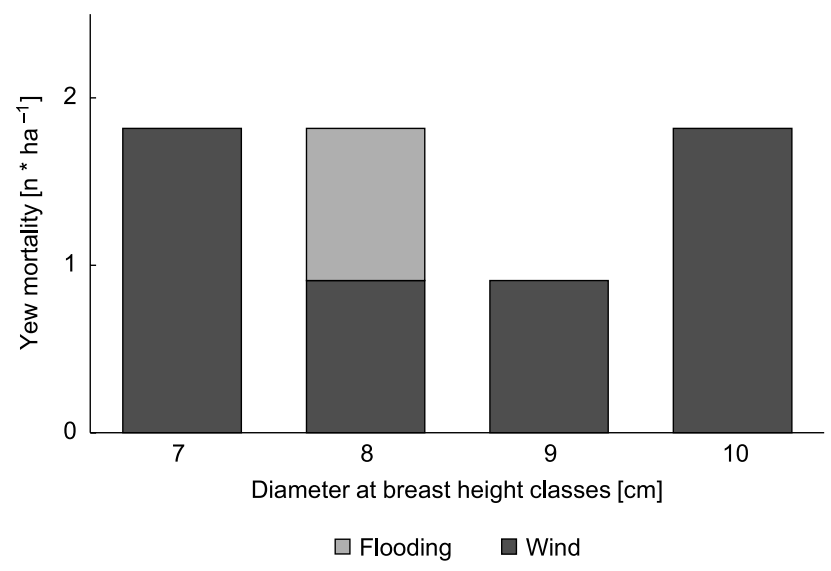

Fig. 2. Number of yews which died on the sampling plots in the years 2001-2017 and causes of their mortality 
Table 2. Spearman correlation matrix of variables (characteristics of 22 sampling plots)

\begin{tabular}{|c|c|c|c|c|c|c|c|c|c|c|}
\hline & $\begin{array}{l}\text { Stand } \\
\text { volume } \\
2007\end{array}$ & $\begin{array}{l}\text { Stand } \\
\text { volume } \\
2017\end{array}$ & $\begin{array}{c}\text { Number } \\
\text { of trees } \\
2007\end{array}$ & $\begin{array}{l}\text { Number } \\
\text { of trees } \\
2017\end{array}$ & $\begin{array}{c}\text { Basal area } \\
2007\end{array}$ & $\begin{array}{l}\text { Basal } \\
\text { area } \\
2017\end{array}$ & $\begin{array}{l}\text { Sapling } \\
\text { and } \\
\text { shrub } \\
\text { density } \\
\end{array}$ & $\begin{array}{l}\text { Canopy } \\
\text { cover } \\
2017\end{array}$ & $\begin{array}{c}\text { Number } \\
\text { of yews } \\
(\mathrm{DBH} \geq 7 \\
\mathrm{cm})\end{array}$ & $\begin{array}{c}\text { Soil moisture } \\
\text { based on } \\
\text { herbaceous } \\
\text { vegetation }^{1}\end{array}$ \\
\hline $\begin{array}{l}\text { Stand volume } \\
2017\end{array}$ & $0.92^{* * *}$ & & & & & & & & & \\
\hline $\begin{array}{l}\text { Number of } \\
\text { trees } 2007\end{array}$ & -0.12 & -0.02 & & & & & & & & \\
\hline $\begin{array}{l}\text { Number of } \\
\text { trees } 2017\end{array}$ & -0.26 & -0.15 & $0.95^{* * *}$ & & & & & & & \\
\hline $\begin{array}{l}\text { Basal area } \\
2007\end{array}$ & $0.82^{* * *}$ & $0.85^{* * *}$ & 0.28 & 0.16 & & & & & & \\
\hline $\begin{array}{l}\text { Basal area } \\
2017\end{array}$ & $0.60^{* *}$ & $0.79^{* * *}$ & $0.47^{*}$ & 0.40 & $0.84^{* * *}$ & & & & & \\
\hline $\begin{array}{l}\text { Sapling and } \\
\text { shrub density }\end{array}$ & 0.38 & 0.32 & -0.18 & -0.31 & 0.22 & 0.06 & & & & \\
\hline $\begin{array}{l}\text { Canopy cover } \\
2017\end{array}$ & 0.04 & 0.21 & 0.35 & 0.38 & 0.08 & 0.34 & -0.27 & & & \\
\hline $\begin{array}{l}\text { Number of } \\
\text { yews }(\mathrm{DBH} \geq \\
7 \mathrm{~cm})\end{array}$ & -0.21 & -0.27 & 0.26 & 0.29 & -0.09 & -0.16 & 0.11 & 0.15 & & \\
\hline $\begin{array}{l}\text { Soil moisture } \\
\text { based on } \\
\text { herbaceous } \\
\text { vegetation }\end{array}$ & $0.60^{* *}$ & $0.44^{*}$ & -0.13 & -0.25 & $0.52^{* *}$ & 0.20 & 0.37 & $-0.44^{*}$ & -0.13 & \\
\hline $\begin{array}{l}\text { Herbaceous } \\
\text { vegetation } \\
\text { density }\end{array}$ & $0.59^{* *}$ & 0.42 & -0.25 & -0.31 & $0.47^{*}$ & 0.15 & $0.50^{*}$ & $-0.47^{*}$ & -0.19 & $0.86^{* * *}$ \\
\hline
\end{tabular}

Significance: ${ }^{* *} p<0.05,{ }^{* *} p<0.01,{ }^{* * *} p<0.001 .{ }^{1}$ The variable "soil moisture" expresses the ground cover proportion of herbaceous plants characteristic of moist, wet, and aquatic sites (Zarzycki et al., 2002) as compared to plants typical of the less moist sites.

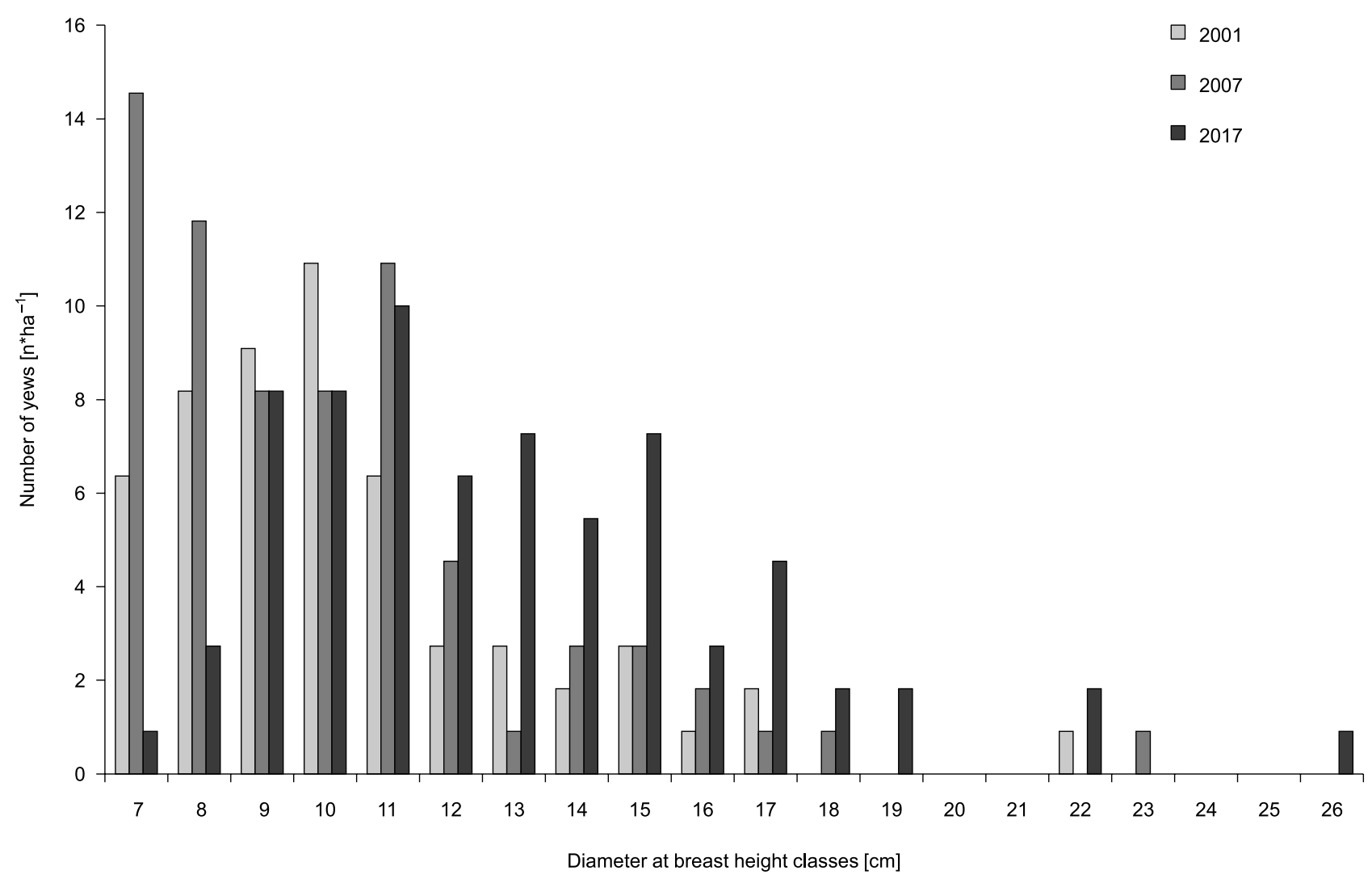

Fig. 3. Diameter at breast height structure of English yews; data from 2001 according to Warcicki (2001) and from 2007 according to Bujoczek et al. (2009) 


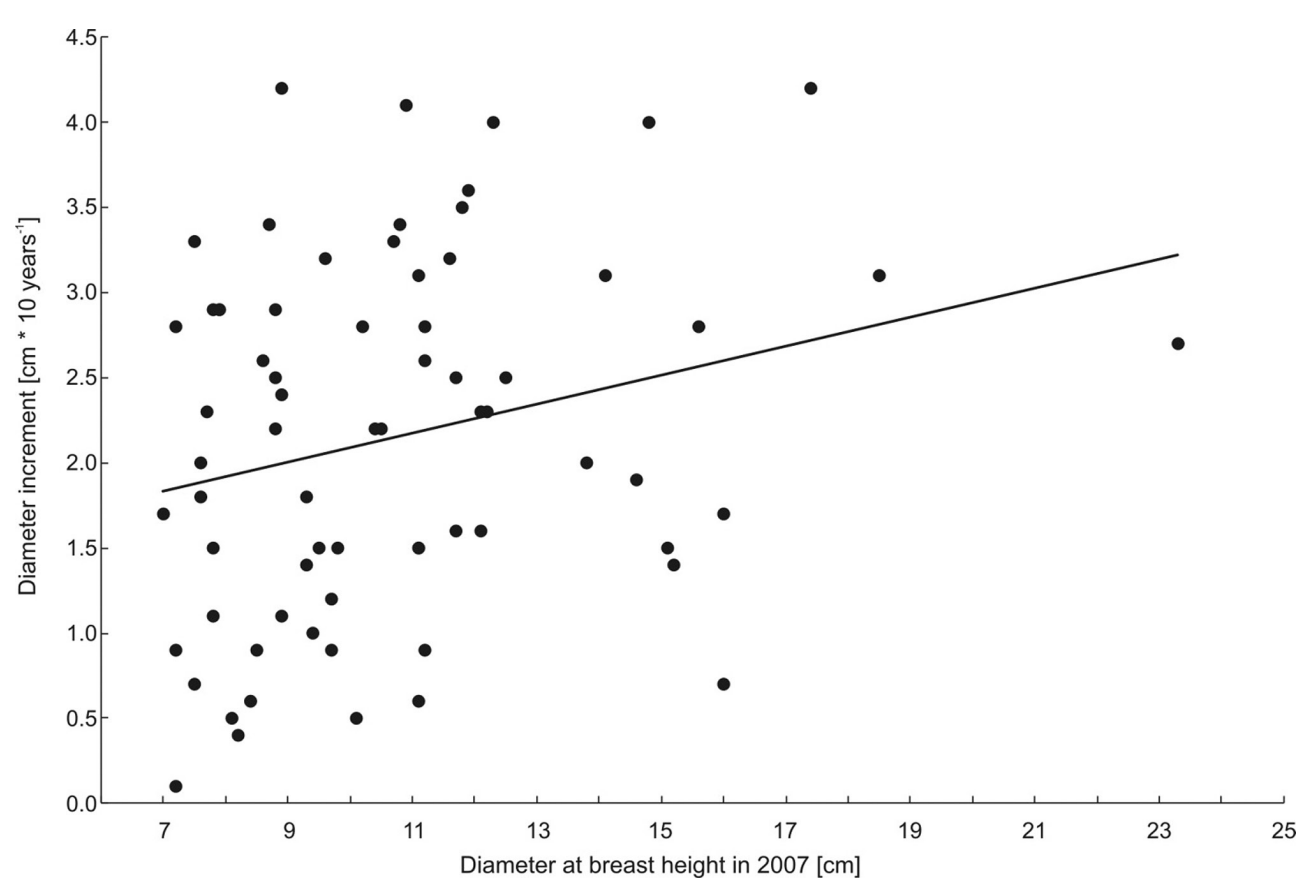

Fig. 4. Relationship between 2007 DBH values and diameter increments in 2007-2017 $\left(y=0.0848 x+1.2443 ; R^{2}=0.06\right.$; $\mathrm{p}<0.05 ; \mathrm{n}=70$ )

tree layer, while 6.4 individuals/ha died. The causes of mortality were periodic flooding and, indirectly, wind, as large uprooted trees of other species impacted the nearby yews with a DBH of 7-10 cm (Fig. 2).

Over the 16 years of study, the change in the yew diameter structure was pronounced, with a declining number of the thinnest individuals and an increasing density of yews with DBH $>12 \mathrm{~cm}$, especially in the years 2007-2017 (Fig. 3). The maximum recorded DBH of a yew was $26 \mathrm{~cm}$ (in 2017). In the 20072017 period, the mean DBH increment was $2.2 \pm 0.1$ $\mathrm{mm}$ /year. Multiple regression analysis did not find the independent variables describing the tree stand and habitat (Table 1) to have a significant effect on the diameter increment. The only independent predictor of the dependent variable was yew DBH at the beginning of the observation period, that is, in 2007 $(p<0.05)$, with thicker yews exhibiting a slightly greater increment than thinner ones. However, the regression coefficient $R^{2}$ for the model was 0.06 , which means that it largely depended on variables not contained in the analysis (Fig. 4).

Some herbaceous vegetation species were found in both forest types, but most of them had a considerably greater presence in one or the other forest type. The most abundant herbaceous plants mainly occurring in the moist coniferous forest were: Anemone nemorosa $\mathrm{L}$. (species found in 4 out of 22 sampling plots), Galeobdolon luteum Huds. emend. Holub (3), Mercurialis perensis L. (5), Oxalis acetosella L. (6), Pteridium aquilinum (L.) Kuhn (4), and Vaccinium sp. (6). The species typically found in the alder swamp forest were: Aegopodium podagraria L. (9), Berula erecta (Huds.) Coville (3),
Caltha palustris L. (4), Carex sp. (14), Cardamine amara L. (4), Chrysosplenium alternifolium L. (7), Cirsium oleraceum (L.) Scop. (5), Crepis paludosa L. (7), Geum rivale L. (8), Lycopus europaeus L. (7), Lysimachia sp. (9), Juncus sp. (12), Mentha aquatica L. (3), Myosotis palustris L. (11), Peucedanum palustre (L.) Moench (3), Solanum dulcamara L. (3), Urtica dioica L. (5), and Viola palustris L. (2). Other species, which were equally abundant in both forest types, were: Dryopteris sp. (8), Hedera helix L. (12), Rubus sp. (16).

Yew regeneration was found in half of the 22 sampling plots, all of which featured seedlings, and three additionally revealed yew saplings. The mean density of saplings was $55 \pm 41$ individuals/ha. All saplings were more than $1.3 \mathrm{~m}$ high, with $\mathrm{DBH}$ mostly between 4.0 and $6.9 \mathrm{~cm}$. However, in this case differences in density between size classes were not statistically different as the vast majority of sampling plots revealed no yew saplings (Kruskal-Wallis test $\mathrm{H}=$ 3.0, $p>0.05$ ). The seedling density was $1005 \pm 334$ individuals/ha, with $90 \%$ of the seedlings being less than $10 \mathrm{~cm}$ high, and none of them exceeding $30 \mathrm{~cm}$ (Fig. 5). Differences in density were statistically significant between seedlings less than $10 \mathrm{~cm}$ high and the other groups (Kruskal-Wallis test $\mathrm{H}=36.3, p$ $<0.001)$. Considerable browsing damage, probably caused by cervids, was evident: it affected all seedlings in the $21-30 \mathrm{~cm}$ height category, $70 \%$ in the $11-20 \mathrm{~cm}$ category, and $30 \%$ in the $<10 \mathrm{~cm}$ category.

The likelihood of yew seedling occurrence was found to be significantly influenced by: the presence of mature yews in the tree layer, soil moisture, and the density of herbaceous vegetation, with the latter 


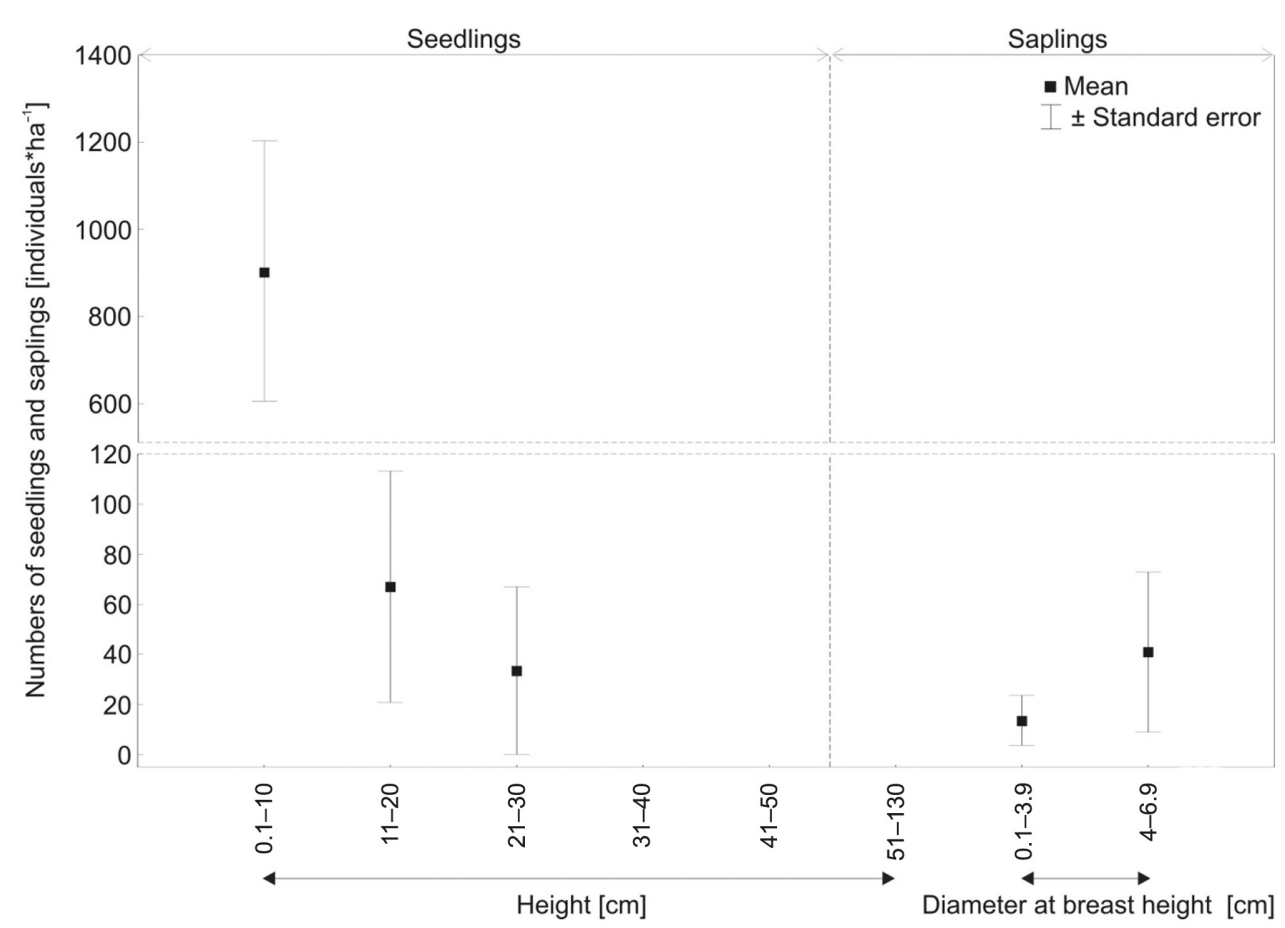

Fig. 5. Density of English yew regeneration in 2017

two variables being strongly intercorrelated. Thus, the model included two independent values, which improved its quality (Table 3 ). The likelihood of seedling occurrence increased in the presence of mature yews on the sampling plot, which was a dichotomous variable $(0-1)$, but it was not affected by the number of yews on the plot. The other significant variable was soil moisture, determined on the basis of herbaceous vegetation. The greater the proportion of plants with moist, wet, and aquatic moisture indicators on the sampling plot, the lower the likelihood of seedling occurrence. While the independent variables describing tree stand characteristics did not directly improve the model, it should be noted that they did exert an influence on the significant variables affecting the occurrence yew seedlings. The soil moisture variable exhibited positive correlations with such stand features as stand volume and a negative association with canopy cover. Herbaceous vegetation density exhibited strong positive correlations with stand volume and sapling and shrub density, and a negative association with canopy cover (Table 2).

\section{Discussion}

The yew is a tree that has long been threatened in Europe despite some localized increases. Yew populations are subjected to various local environmental influences. The site conditions in the studied Jasien Nature Reserve are mostly determined by high water table levels and the streams flowing through it, making it a mosaic of areas with varying degrees of soil moisture. This has a significant effect both on the species composition of trees, shrubs, and herbaceous vegetation, as well as on the development of the yew population. While the overall size of the latter has not changed considerably over the past several decades (Mowszowicz \& Urbanek, 1960; Bujoczek et al., 2009), a gradual rise in yew dimensions has been noted. Indeed, in the years 2001-2017 the number of yews in the tree layer has substantially increased (by 15 individuals/ha). However, the low sapling density shows that the recruitment of yews to the tree layer will stall in the near future, and so in the long term the yew population may decline.

Table 3. Logistic regression results for the likelihood of English yew seedlings occurrence within sampling plots

\begin{tabular}{lcccc}
\hline \multicolumn{1}{c}{ Independent variable } & $\beta$ (standard error) & Wald's chi-square & Odds ratio (95\% confidence interval) & $\mathrm{p}$ \\
\hline $\begin{array}{l}\text { Presence of mature } \\
\text { yews on sampling plot }\end{array}$ & $4.575(2.274)$ & 4.046 & $97.04(1.12-8375.30)$ & 0.044 \\
$\begin{array}{l}\text { Soil moisture based on } \\
\text { herbaceous vegetation }\end{array}$ & $0.056(0.028)$ & 3.964 & $0.945(0.895-0.999)$ & 0.046 \\
Intercept & $-0.787(1.677)$ & 0.220 & & 0.639 \\
\hline
\end{tabular}

${ }^{1}$ The variable "soil moisture" expresses the ground cover proportion of herbaceous plants characteristic of moist, wet, and aquatic sites (Zarzycki et al., 2002) as compared to plants typical of the less moist sites. Quality characteristics of the model: Likelihood-ratio test: $\chi^{2}=14.9 ; p<0.001$. Coefficients: Cox-Snell's $R^{2}-0.492$, Nagelkerke's $R^{2}-0.656$. The model correctly predicted the results in $91 \%$ of the cases. Hosmer-Lemeshow test $=7.94 ; p=0.338$. 
An average of 6-7 yews/ha died over the analyzed 16 years. The most significant of the identified mortality causes was strong wind, which toppled large trees onto yews. This was previously described in this area as a factor which may rapidly decimate the yew population. In 1960, a gale caused alder windthrow, which also uprooted 200 yews (Baluta \& Mowszowicz, 1966). Climate change seems to intensify extreme weather events (Pryor et al., 2005; Pryor \& Barthelmie, 2010), and gale-force winds are increasingly often recorded in Poland. Therefore, in addition to the aforementioned effects of climate change on the yew population in the south of its range resulting from increased drought and fire frequency (Thomas \& Garcia-Marti, 2015), the species is likely to suffer considerable damage in the central regions of its range due to intensifying gales. The risk of wind damage can also be reduced to some extent by various forest treatments (Zachara, 2006). For instance, it has been noted that wind-impermeable stand edges cause increased turbulence in the canopy deeper in the stand, which may exacerbate damage. Thus, a properly formed stand margin should consist of strong and tapering trees, whose crowns let air flow into the stand, where wind becomes diffused, with its speed gradually reduced (Zajączkowski, 1991). However, in the case of gale-force winds damage cannot be completely avoided. In particular, shallow-rooted yews are more vulnerable to windthrow, whether direct or indirect (Thomas \& Polwart, 2003). Small yew populations, which are critical to the conservation of the species, may be quickly destroyed by wind.

According to Litkowiec et al. (2013), the choice of populations for ex situ conservation based solely on their actual size might be misguided as relatively large populations may exhibit a considerable degree of inbreeding and low genetic variation. In turn, much smaller populations may be characterized by low inbreeding and high genetic variability. One should also take into account the role of entire ecosystems with substantial yew presence as habitats for other rare organisms (Chachuła et al., 2016).

The other causes of mortality include excessive soil moisture and periodic flooding, which gradually eliminate yews from the affected sites. Although the problem of yew mortality due to flooding is not serious at the moment, it is potentially a major threat. For example, a large part of the yew reserve in nearby Radomice (Poland) has died as a result of beaver dams (oral communication from the Forest Department). Hydrological conditions may thus significantly modify yew distribution in the studied nature reserve, limiting its occurrence to places where moisture is not excessive. The absence of random distribution and the formation of clusters has been reported for this species from other stands (Hylla \& Dobrowolska, 2015). Also in the Jasień Nature
Reserve, yews tend to form clusters rather than a uniform distribution pattern, as described in a previous work (Bujoczek et al., 2009).

Research shows that yew seeds can germinate under the canopy of many tree species, (Giertych, 2000; Bîrsan et al., 2017). However, the type of tree stand also affects the development of ground vegetation, saplings and shrubs, which directly compete with yew seedlings. The studied stand characteristics did not significantly influence the likelihood of yew seedling occurrence, despite taking into consideration data both from 2007, when regeneration was being formed, and the present results, describing the current state of the forest in which the yews grow. Nevertheless, stand characteristics were correlated with the factors which were found to be significant in the developed regression model. Higher soil moisture was associated with lower canopy cover and greater stand volume. That was the case for areas with dominant alders, whose open crowns allowed a substantial amount of light to reach the forest floor and stimulated the growth of ground vegetation. Soil moisture levels for the sampling plots varied markedly from fresh to wet. An increase in the proportion of herbaceous plants on the sampling site with a soil moisture indicator above the fresh-moist level considerably decreased the likelihood of yew seedling occurrence, which was strongly correlated with herbaceous vegetation density. According to Iszkuło et al. (2005), excessive exposure to sunlight may eliminate the youngest seedlings as they may not be able to compete with fast-growing herbs and the seedlings of broad-leaved trees.

Research has shown that the youngest yew seedlings (to $6.0 \mathrm{~cm}$ tall) can germinate and grow in very shady conditions within the stand, with the number of yews decreasing in plots with increasing photosynthetic photon flux density (PPFD) (Iszkuło \& Boratyński, 2006). Low PPFD under the stand canopy is likely to significantly reduce competition from other plants. Taller yews, with a height of up to $100 \mathrm{~cm}$, are observed most frequently in areas with $2-7 \%$ relative PPFD. Thus, the small numbers of older, taller seedlings in deep shade is thought to be associated with a higher mortality rate of seedlings less than $6 \mathrm{~cm}$ high without recruitment to the next height class. In the case of the Jasien Nature Reserve, the number of yew seedlings abruptly decreases with increasing height, which also indicates low survivorship. Canopy cover varies moderately, ranging from $20 \%$ to $75 \%$. Thus, on the studied site there are no areas that would be densely shaded by the tree layer. However, the layer of saplings and shrubs is very well developed, which may actually exert a positive influence on yew seedlings. Nurse shrubs are known to serve as protection from herbivores (Farris \& Filigheddu, 2008). According to Devaney et al. (2014), the density of natural 
young yew regeneration and the abundance of shrubs are positively correlated. Therefore, the relationships between stand characteristics and yew growth are dynamic. Indeed, Devaney et al. (2015) highlighted the importance of considering all life-history stages and multiple traits when evaluating species response to light availability.

The other significant factor is the presence of mature yews in the tree layer, which is non-trivial because yew seed dispersal is also mediated by animals (García et al., 2000; García et al., 2005). A greater number of seedlings in the vicinity of mature trees, rather than far from them, was also found in other sites. For example, in the Bieszczady Mountains, yew seedlings were concentrated exclusively in the neighborhood of larger groups of mature individuals. Apart from that, yew seedlings were recorded only sporadically across the entire nature reserve (Bodziarczyk \& Rużyło, 2007). In turn, Devaney et al. (2014) reported that high densities of conspecific adults were negatively related to the recruitment likelihood of yew regeneration and that yew regeneration was reduced beneath conspecific canopies. Since regeneration was the highest in nearby areas, the authors suggested that an intermediate dispersal distance maximized recruitment probability. As a result, areas adjacent to existing yew stands are most likely to represent optimal sites for regeneration. Thus, in the present study, of crucial importance may be the excessive soil moisture in areas neighboring the current locations of mature yews, limiting the spread of yew regeneration and causing its concentration in close proximity of mature yews.

In the studied area, the number of seedlings was moderate. For comparison, in a protected area in the Ukrainian Carpathians, yew seedling density ranged from more than 10 thousand to almost 30 thousand individuals per hectare, depending on the year of study (Iszkuło et al., 2005). However, it should be noted that also the density of yews in the tree layer was several-fold higher in the Ukrainian reserve. In turn, seedling density in the Bieszczady was three times lower (352 individuals/ha) than in the Jasien reserve (Bodziarczyk \& Rużyło, 2007). Finally, Dobrowolska et al. (2012) reported values similar to those found in the present work: 133 to $1167<0.5$ $\mathrm{m}$ high individuals per hectare. In addition, in the study of Dobrowolska et al. (2012), the degree of yew regeneration depended on competition from herbaceous vegetation (the greater the percentage ground cover, the smaller the yew regeneration). Nevertheless, it should be noted that in the case of research on seedlings density, of importance is the season during which observations are made. For instance, a seedling survey in autumn and in the spring of the following year gave drastically different results in the Wierzchlas Nature Reserve (Iszkuło et al., 2012b).
Given the current conservation status of the English yew, many authors have observed the need to implement active protection of this species (Iszkuło et al., 2016; Dobrowolska et al., 2017). Thomas \& Garcia-Marti (2015) claim that without intervention, the yew will survive by inertia in the short-term, but eventually will become extinct in most areas. Of equal concern is the future loss of old, veteran individuals and the associated biodiversity. Thus, conservation measures should be comprehensive and take into account geographical location and dominant environmental stressors. Given the history of the yew population in the studied nature reserve, the factors influencing it, and the implemented measures, it should be noted that despite high soil moisture the conditions for yew development are favorable. The population may be deemed young and maturing. The yew is a long-lived species and intermittent regeneration is sufficient to replace mature trees. The present regeneration, which is moderate in the lowest layers, is absent for the height range from $0.3 \mathrm{~m}$ to 1.3 $\mathrm{m}$. Most of the yew saplings growing out of the herbaceous vegetation layer were browsed. In the mid20th century, regeneration significantly improved in this area several years after the nature reserve was fenced off, with height increments of up to $15 \mathrm{~cm}$ per year (Urbanek, 1960). However, at that time browsing was mostly caused by grazing cattle. In a study of a mixed forest by Kýpetová et al. (2018), it was found that grazing had a negative significant impact both on the growth rate and needle morphology of saplings. Those damaged by herbivores exhibited approximately a third of the height increment of nongrazed saplings. The influence of deer, can be even stronger in better light condition. After the elimination of grazing, browsed yews had a greater tendency to form a polycormic (multi-stemmed) habit. The authors concluded that lower growth rates, smaller needles, and polycormic stems indicate a strategy of "escaping" herbivory pressure even up to several years after the elimination of deer browsing.

\section{Conclusion}

The abundance and survivorship of regeneration are of primary concern in the studied nature reserve. This is all the more important as periodic windthrows deplete the base of seed-producing yews. However, the main problem of this population is not the mortality of old trees, but the absence of recruitment of young individuals to older age classes. While browsing is definitely a significant factor, the effects of the various stand characteristics should be further investigated. Some of those features, such as seedling and shrub density, do not vary considerably across the reserve, which makes it difficult to establish their 
influence on yew regeneration. Habitat conditions range from fresh to very wet. Excessive soil moisture and periodic flooding are detrimental to population development. These factors are of major importance given the fact that the studied nature reserve includes several streams and neighbors fish ponds.

\section{Acknowledgments}

The authors thank the anonymous Reviewers for their comments, which have greatly contributed to the improvement of an earlier version of this manuscript. This study was financed by the Ministry of Science and Higher Education of the Republic of Poland.

\section{References}

Adamczyk J (2011) Cisy pospolite (Taxus baccata L.) w Nadleśnictwie Wipsowo, w obrębie Purda Leśna. Rocznik Polskiego Towarzystwa Dendrologicznego 59: 67-75.

Baluta R \& Mowszowicz J (1966) Rezerwaty leśne województwa łódzkiego. Sylwan 110: 53-64.

Bîrsan C, Mardari C, Copoț O \& Apăştinei L (2017) Development of Taxus baccata L. population under tree canopy in the Tudora Reservation. Acta Oecologica Carpatica 10: 37-50.

Bodziarczyk J \& Rużyło T (2007) Warunki występowania, struktura oraz stan zdrowotny populacji cisa pospolitego Taxus baccata L. W rezerwacie przyrody „Cisy na Górze Jawor” w Bieszczadach. Roczniki Bieszczadzkie 15: 163-179.

Bugała W (1975) Cis pospolity. Monografie popularno naukowe. Nasze drzewa leśne. PWN, Warszawa, Poznań.

Bujoczek L, Bujoczek M, Przybylska K \& Warcicki R (2009) Stan i dynamika cisa pospolitego Taxus baccata L. W drzewostanach na siedlisku boru wilgotnego i olsu rezerwatu przyrody „Jasień”. Chrońmy Przyrodę Ojczystą 65: 375-384.

Chachuła P, Bodziarczyk J, Kozubek R, Widlak M, \& Siwy M (2016) Grzyby wielkoowocnikowe występujące $w$ lasach jodłowo-bukowych $z$ udziałem cisa pospolitego Taxus baccata L. w Polskich Karpatach. Roczniki Bieszczadzkie 24: 53-85.

Czuraj M (1990) Tablice miąższości kłód odziomkowych i drzew stojących. PWRiL, Warszawa.

Decision of Minister of Forestry and Wood Industry (1958) Zarządzenie Nr 325 Ministra Leśnictwa i Przemysłu Drzewnego. Nr O.P.-244/119 - Monitor Polski Nr 92 poz. 509.

Decision of the General Director of State Forests (2006) Zarządzenie nr 29 Dyrektora Generalnego Lasów Państwowych z 30 czerwca 2006 r. w sprawie wprowadzenia $\mathrm{w}$ jednostkach organizacyjnych Państwowego Gospodarstwa Leśnego Lasy
Państwowe „Programu ochrony i restytucji cisa pospolitego (Taxus baccata L.) w Polsce".

Decision of the Regional Director of the Environment Protection (2013) Zarządzenie Nr 38/2013 Regionalnego Dyrektora Ochrony Środowiska w Łodzi. Dz. Urz. z 2013 r. poz. 3528.

Devaney JL, Jansen MAK \& Whelan PM (2014) Spatial patterns of natural regeneration in stands of English yew (Taxus baccata L.); Negative neighbourhood effects. Forest Ecology and Management 321: 52-60.

Devaney JL, Whelan PM \& Jansen MAK (2015) Light responses of yew (Taxus baccata L.); does size matter? Trees 29: 109-118. doi:10.1007/s00468-0141095-x.

Dhar A, Ruprecht H, Klumpp R \& Vacik H (2006) Stand structure and natural regeneration of English yew (Taxus baccata L.) at Stiwollgraben in Austria. Dendrobiology 56: 19-26.

Directive of the Minister of Environment (2014) Rozporządzenie Ministra Środowiska $z$ dnia 9 października 2014 r. w sprawie ochrony gatunkowej roślin. Dz.U. 2014 poz. 1409.

Dobrowolska D, Olszowska G \& Niemczyk M (2012) Struktura drzewostanów a populacje cisa pospolitego (Taxus baccata L.) w rezerwatach przyrody „Cisy Rokickie” i „Bogdanieckie Cisy”. Leśne Prace Badawcze 73: 313-322.

Dobrowolska D, Niemczyk M \& Olszowska G (2017) The influence of stand structure on European yew Taxus baccata populations in its natural habitats in Central Poland. Polish Journal of Ecology 65: 369384. doi:10.3161/15052249PJE2017.65.3.005.

Farris E \& Filigheddu R (2008) Effects of browsing in relation to vegetation cover on common yew (Taxus baccata L.) recruitment in Mediterranean environments. Plant Ecology 199: 309-318.

Frydel K \& Nawrocka-Grzeskowiak U (2009) Cis pospolity (Taxus baccata L.) w Nadleśnictwie Kaliska. Zarządzanie Ochroną Przyrody w Lasach 3: 155-161.

Garbarino M, Weisberg PJ, Bagnara L \& Urbinati C (2015) Sex-related spatial segregation along environmental gradients in the dioecious conifer, Taxus baccata. Forest Ecology and Management 358: 122-129. doi:10.1016/j.foreco.2015.09.009.

García D, Zamora R, Hódar JA, Gómez JM \& Castro J (2000) Yew (Taxus baccata L.) regeneration is facilitated by fleshy-fruited shrubs in Mediterranean environments. Biological Conservation 95: 31-38. doi:10.1016/S0006-3207(00)00016-1.

García D, Obeso JR \& Martínez I (2005) Rodent seed predation promotes differential recruitment among bird-dispersed trees in temperate secondary forests. Oecologia 144: 435-446. doi:10.1007/ s00442-005-0103-7. 
Giertych P (2000) Factors determining natural regeneration of yew (Taxus baccata L.) in the Kórnik Arboretum. Dendrobiology 45: 31-40.

Gieruszyński T (1961) Struktura i dynamika rozwojowa drzewostanów rezerwatu cisowego w Wierzchlesie. Ochrona Przyrody 27: 41-90.

Hultén E \& Fries M (1986) Atlas of North European vascular plants north of the Tropic of Cancer. Koeltz Scientific.

Hylla W \& Dobrowolska D (2015) Rozmieszczenie populacji cisa pospolitego (Taxus baccata L.) W rezerwacie "Cisy nad Liswartą". Sylwan 159: 948-957.

Introduction to SAS (2007) UCLA: Academic Technology Services, Statistical Consulting Group. http://www.ats.ucla.edu/stat/mult_pkg/faq/gen$\mathrm{eral} / \mathrm{psuedo}$ rsquareds.htm.

Iszkuło G (2001) The yew (Taxus baccata L.) of the Cisowy Jar reserve near Olecko. Dendrobiology 46: 33-37.

Iszkuło G (2010) Success and failure of endangered tree species: low temperatures and low light availability affect survival and growth of European yew (Taxus baccata L.) seedlings. Polish Journal of Ecology 58: 259-271.

Iszkuło G \& Boratyński A (2006) Analysis of the relationship between photosynthetic photon flux density and natural Taxus baccata seedlings occurrence. Acta Oecologica 29: 78-84. doi:10.1016/j. actao.2005.08.001.

Iszkuło G, Boratyński A, Didukh Y, Romaschenko K \& Pryazhko N (2005) Changes of population structure of Taxus baccata L. during 25 years in protected area (Carpathians, Western Ukraine). Polish Journal of Ecology 53: 13-23.

Iszkuło G, Didukh Y, Giertych MJ, Jasińska AK, Sobierajska K \& Szmyt J (2012a) Weak competitive ability may explain decline of Taxus baccata. Annals of Forest Science 69: 705-712. doi:10.1007/ s13595-012-0193-4.

Iszkuło G, Golimowski R, Lewandowska A, Wachowiak E \& Boratyński A (2012b) Zmiany roślinności w rezerwacie "Cisy Staropolskie im. Leona Wyczółkowskiego" koło Wierzchlasu w Borach Tucholskich. Sylwan 156: 163-169.

Iszkuło G, Nowak-Dyjeta K \& Sękiewicz M (2014) Influence of initial light intensity and deer browsing on Taxus baccata saplings: a six years field study. Dendrobiology 71: 93-99. doi:10.12657/ denbio.071.009.

Iszkuło G, Pers-Kamczyc E, Nalepka D, Rabska M, Walas $Ł$ \& Dering M (2016) Postglacial migration dynamics helps to explain current scattered distribution of Taxus baccata. Dendrobiology 76: 81-89. doi:10.12657/denbio.076.008.

Kassioumis K, Papageorgiou K, Glezakos T \& Vogiatzakis IN (2004) Distribution and stand structure of Taxus baccata populations in Greece; Results of the first national inventory. Ecologia Mediterranea 30: 159-170.

Katsavou I \& Ganatsas P (2012) Ecology and conservation status of Taxus baccata population in NE Chalkidiki, northern Greece. Dendrobiology 68: 55-62.

Kotkowski K (1930) Obecny stan rezerwatu cisowego w Jasieniu koło Radomska. Czasopismo Przyrodnicze 5-7: 188-191.

Król S \& Gołąb W (1996) Bibliografia cisa pospolitego Taxus baccata L. w Polsce. Wydawnictwo Sorus, Poznań.

Krupiński KM, Żarski M \& Nawrocki J (2004) Reinterpretacja geologiczno-stratygraficzna osadów interglacjału mazowieckiego $\mathrm{W}$ Wylezinie koło Ryk. Przegląd Geologiczny 52: 683-692.

Kruszelnicki J (2001) Taxus baccata L. Cis pospolity: Polish red data book of plants (ed. by R Kazimierczakowa \& K Zarzycki) W. Szafer Institute of Botany, Polish Academy of Science, Kraków, pp. 68-70.

Kýpetová M, Walas Ł, Jaloviar P \& Iszkuło G (2018) Influence of herbivory pressure on the growth rate and needle morphology of Taxus baccata L. juveniles. Dendrobiology 79: 10-19. doi:10.12657/ denbio.079.002.

Larose DT (2008) Data mining methods and models. Wydawnictwo Naukowe PWN, Warszawa.

Litkowiec M, Plitta BP \& Lewandowski A (2013) Znaczenie zmienności genetycznej dla ochrony zasobów genowych cisa pospolitego w Europie. Sylwan 157: 754-760.

Litkowiec M, Lewandowski A \& Wachowiak W (2018) Genetic variation in Taxus baccata L.: A case study supporting Poland's protection and restoration program. Forest Ecology and Management 409: 148-160.

Malitowski J (1922) Las cisowy w Jasieniu. Ochrona Przyrody 3: 58-61.

Menard S (2001) Applied logistic regression analysis. Sage University Paper Series on Quantitative Applications in the Social Sciences 106. Sage, Thousand Oaks, CA.

Mowszowicz J \& Urbanek H (1960) Obecny stan rezerwatu cisa $\mathrm{W}$ Jasieniu pod Radomskiem. Chrońmy Przyrodę Ojczystą 16: 6-14.

Myking T, Vakkari P \& Skrøppa T (2009) Genetic variation in northern marginal Taxus baccata L. populations. Implications for conservation. Forestry 82: 529-539.

Nawrocka-Grześkowiak U, Skuza L \& Szućko I (2015) Zmienność genetyczna cisa w wybranych rezerwatach Polski. Sylwan 159: 491-497.

Perrin PM \& Mitchell FJ (2013) Effects of shade on growth, biomass allocation and leaf morpholo- 
gy in European yew (Taxus baccata L.). European Journal of Forest Research 132: 211-218.

Plan of Forest Management (1984) Plan urządzania rezerwatu częściowego Jasień, na okres od 01 I 1984 r. do 31 XII 1993 r. Nadleśnictwo Radomsko, Obręb Kobiele Wielkie, OZLP w Łodzi.

Pridnya MV (2002) Taxus baccata in the Caucasus region. Der Eibenfreund 9: 146-165.

Pryor SC \& Barthelmie RJ (2010) Climate change impacts on wind energy: A review. Renewable and Sustainable Energy Reviews 14: 430-437. doi:10.1016/j.rser.2009.07.028.

Pryor SC, Schoof JT \& Barthelmie RJ (2005) Climate change impacts on wind speeds and wind energy density in northern Europe: empirical downscaling of multiple AOGCMs. Climate Research 29: 183-198. doi:10.3354/cr029183.

Robakowski P \& Wyka T (2009) Winter photoinhibition in needles of Taxus baccata seedlings acclimated to different light levels. Photosynthetica 47: 527-535.

Ruprecht H, Dhar A, Aigner B, Oitzinger G, Klumpp R \& Vacik H (2010) Structural diversity of English yew (Taxus baccata L.) populations. European Journal of Forest Research 129: 189-198. doi:10.1007/s10342-009-0312-4.

Seidl R, Rammer W \& Blennow K (2014) Simulating wind disturbance impacts on forest landscapes: tree-level heterogeneity matters. Environmental Modelling \& Software 51: 1-11.

Seidling W (1999) Spatial structures of a subspontaneous population of Taxus baccata saplings. Flora 194: 439-451. doi:10.1016/S03672530(17)30934-9.

Svenning J \& Magård E (1999) Population ecology and conservation status of the last natural population of English yew Taxus baccata in Denmark. Biological Conservation 88: 173-182.

Thomas PA \& Garcia-Marti X (2015) Response of European yews to climate change: a review. For- est Systems 24: eR01. doi:10.5424/fs/201524307465.

Thomas PA \& Polwart A (2003) Biological flora of the British Isles. Taxus baccata L. Journal of Ecology 91: 489-524. doi:10.1046/j.13652745.2003.00783.x.

Trapp RJ \& Hoogewind KA (2016) The realization of extreme tornadic storm events under future anthropogenic climate change. Journal of Climate 29: 5251-5265.

Urbanek H (1960) Rezerwat cisowy Jasień. Zeszyty Naukowe Uniwersytetu Łódzkiego, Seria II 8: 105-122.

Warcicki R (2001) Ocena stanu zasobów leśnych rezerwatu cisowego Jasień. Master's thesis. Department of Forest Management, Faculty of Forestry, University of Agriculture in Krakow.

Wyka T, Robakowski P \& Zytkowiak R (2008) Leaf age as a factor in anatomical and physiological acclimative responses of Taxus baccata L. needles to contrasting irradiance environments. Photosynthesis Research 95: 87-99.

Zachara T (2006) Problem szkód w lasach powodowanych przez śnieg i wiatr oraz sposoby przeciwdziałania im. Sylwan 10: 56-64.

Zajączkowski J (1991) Odporność lasu na szkodliwe działanie wiatru i śniegu. Wydawnictwo Świat.

Zarek M (2009) RAPD analysis of genetic structure in four natural populations of Taxus baccata from Southern Poland. Acta Biologica Cracoviensia, Series Botanica 51: 67-75.

Zarek M (2016) Preliminary studies on the molecular identification of sex in Taxus baccata L. Forest Research Papers 77: 68-75. doi:10.1515/frp2016-0008.

Zarzycki K, Trzcińska-Tacik H, Różański W, Szeląg Z, Wołek J \& Korzeniak U (2002) Ecological indicator values of vascular plant of Poland. W. Szafer Institute of Botany. Polish Academy of Science, Kraków. 